\title{
An Evaluation of the Impact of Economic Sanctions on Science Teaching and Learning at Secondary Level in Zimbabwe's Mbire District of Mashonaland Central
}

\author{
Monica Zembere \\ Institution-Bindura University of Science Education, Bindura Zimbabwe
}

Email address:

monizembere69@gmail.com

To cite this article:

Monica Zembere. An Evaluation of the Impact of Economic Sanctions on Science Teaching and Learning at Secondary Level in Zimbabwe's Mbire District of Mashonaland Central. Education Journal. Vol. 4, No. 5, 2014, pp. 194-200.

doi: $10.11648 /$ j.edu. 20150405.12

\begin{abstract}
This article takes stock of the effects of economic sanctions imposed on Zimbabwe in 2000 on science teaching and learning at secondary level. This study was conducted using a descriptive survey design. This method was chosen because it allows the use of a representative sample from a population and that it allows the researcher to handle a larger number of schools within a given period. The impact of sanctions is evaluated for the years between 2006 and 2010 in Mbire district of Mashonaland Central. Four indicators were specifically assessed; these are science teacher- pupil ratio, science laboratories and equipments, brain drain and finally pass rate against overall enrolment. In this article, subjects like integrated science, physical science and mathematics have been selected as subjects of focus for they are central to both economic and technological development. This research has been prompted by high failure rate in these subjects at ordinary level in Mbire which has resulted in high incidences of school dropouts. This could be attributed, probably to social, economic and political pressures mounting on students as a result of sanctions. The researcher feels this has something to do with the nature and quality of educational instruction those pupils in Mbire have been exposed to, resulting in the frustrated child without a full ordinary level certificate. For a period of four years, 2006-2010 Mbire districts in Mashonaland Central has been recording 0\% pass rate in science subjects at ordinary level. Shortage of qualified science teachers has been used to explain these dismal results. The research gathered that between 2000 and 2010 about $80 \%$ of secondary schools in this district were manned by either untrained teachers or primary trained teachers.
\end{abstract}

Keywords: Economic Sanctions, Learning, Educational Attainment

\section{Introduction}

\subsection{Background to the Introduction of Sanctions}

When Zimbabwe attained independence in 1980, the government committed itself to the provision of education with the introduction of free primary education. These reforms on education were meant to realign the colonial education system which was characterized by the colonial legacy of a broader primary education and narrower secondary and tertiary education base. The government of Zimbabwe was successful in the first decade of independence in achieving its educational objectives mainly because of the strength of the national currency which was trading at \$1 Zim against \$1.50 US in 1986 (source). This means that the government was capable of funding all its projects with little or no external financial assistance. From1991 to 1998 , the economy of the country was writhing under the burden of the failed International Monetary Fund's and World Bank's prescribed Economic Structural Adjustment Programme (ESAP). This paper therefore acknowledges that from as early as 1991-1998, the education system in the country was already affected by the negative impact of the structural adjustment programme. In response to the economic hardships ushered in by ESAP, the government had to cut its costs by reducing government budget on education by close to half of its usual budget (Hove 2012). Despite these challenges, the state with the assistance from International Monetary Fund and the World Bank was capable of supporting financially the training of teachers for both primary and secondary schools. More and more qualified teachers were supplied into the education 
system to reduce the proportion of untrained teachers. In 1999, a Presidential Commission on Education and Training chaired by Nziramasanga recommended a wide range of educational reforms with primary focus on teacher education, the sciences, technology and skills (Nziramasanga 1999). This gave way to the establishment of the Scientific and Industrial Research Development Centre (SIRDC) which had the mandate of conducting research in industry and linking it with higher education and learning. The training of science teachers was emphasized. Government grants on science education surpassed that of other subjects (Zvobgo, 1998 ). This was borrowed from (Chombo, 1998) idea that sciences are linked to the socio-economic development of the nation, and that technology and mathematics are widely regarded as the measuring index of a nation's socio-economic and geo-political development. The effects of these reforms have however been thwarted by the adverse economic climate created by the imposed economic sanctions in Zimbabwe.

The expansion and revitalization of education was made possible by the steady supply of funding and learning materials like text books from the International Monetary Fund (IMF) and the World Bank and other nongovernmental organizations because the country was experiencing economic challenges of the consequences of ESAP. The Education Support Programme which was affiliated to the International Monetary Fund facilitated the supply of textbooks, special needs equipment, and construction of school buildings like science laboratories and classrooms in rural areas and marginalised urban areas since 1996. Despite the fact that a lot has been said about the effects of sanctions in Zimbabwe especially on sectors like agriculture, not much has been said on how the sanctions have adversely affected the education sector with special focus on otherwise already impoverished rural areas of Mbire District. To effect, this paper therefore argues that the imposition of sanctions on Zimbabwe had more crippling effects to science teaching and learning especially in rural areas.

\subsection{Why and How Sanctions Were Imposed}

There are two schools of thought that are contradicting on why Zimbabwe was slapped with economic sanctions by the European Union, United States of America and Australia. The first argument is proffered by the Eurocentric analysts who subscribe to the view that sanctions in Zimbabwe are only restrictive measures targeted on President Mugabe and his party officials. This school of thought reiterates that there are no economic sanctions in Zimbabwe and if there are any, they have nothing to do with the economic meltdown in the country (Hove 2012). This school of thought further asserts that President Mugabe's intolerance, human rights abuses, DRC adventure and operation clean up (murambatsvina) have contributed to the economic challenges the country is going through and not sanctions (Chogugudza 2009). The subscribers to this view who are mainly in the political opposition to the ruling party deliberately decided to ignore the impact of western imposed sanctions on the general population of Zimbabwe.

Contesting the Euro-centric ideas are the Afro-centric analysts whose views are championed by the ruling party ZANU PF. Their argument is that sanctions were imposed on the government and people of Zimbabwe for reclaiming their land from the British. They believe sanctions were imposed on ZANU PF to induce suffering on Zimbabweans so that people would vote against their government thereby bringing regime change in the country. ZANU PF politicians argue that Movement for Democratic Change ( MDC) lobbied for these sanctions in a move to use them as a vehicle for regime change, an allegation strongly denied by the MDC party. In 2001, Learnmore Jongwe a legislator in MDC denied that there was any connection between his party and the economic sanctions imposed on the country. (Parliamentary Debates 2001). According to Jongwe, President Mugabe's compulsory acquisition of land which was supported by the constitutional amendment No 17 of 2005 invited for the western imposed sanctions because the constitutional amendment further prevented the courts from challenging any land acquisition programme. (Constitution of Zimbabwe 2007).

The negative and confrontational relations between Zimbabwe and the International community can be traced back to late 1990s when the government of Zimbabwe launched the land reform programme. The Land Acquisition Programme saw several whites losing their land and infrastructure to black farmers without compensation. Britain responded by condemning the land reform programme citing that it was violation of private property rights. According to Fowale (2010) sanctions in Zimbabwe were both declared and undeclared because in 1998 the International Monetary Fund (IMF) imposed unpublicized sanctions under the instigation of Britain and the US in which Britain reversed its pledge on Land reform despite its earlier commitment to support Land Reform and Rehabilitation Phase 11 (LRRP11) in Harare the same year. The following year (1999) IMF completely suspended its support for economic adjustment and reform in Zimbabwe. In 2000, Britain mobilised other members of the European Union and USA to impose sanctions on Zimbabwe in a bid to punish Mugabe's government. This call by Britain was responded to abruptly by the International Development Association (IDA) which suspended all structural adjustment loans to Zimbabwe In May of 2000, leaving Zimbabwe desperate for badly needed funds. Britain further cancelled an aid package to Zimbabwe in 2001 worth US 5 million dollars (Fowale 2010).

United States of America answered to this call for sanctions by passing the Zimbabwe Democracy Economic Recovery Act of 2001 section 4(c) subsection1.This act directed the US executive director to each International financial institution to oppose the vote against any extension by the respective institution of any loan,credit, or 
guarantee to the government of Zimbabwe; or any cancellation or reduction of indebtedness owed by the government of Zimbabwe to the United States of America or any International financial institution.(Fowale 2010) The effect of the imposition of ZIDERA on Zimbabwe was the moving out of a sizeable number of non-governmental organizations from the country with the implication of worsening the economic situation in Zimbabwe. From a realist perspective, the ruling government created the environment for the imposition of sanctions by the west by compulsorily acquiring the land, while the MDC allowed itself to be used by the west in its regime change agenda. (Hove 2012)

\subsection{Statement of the Problem}

Although children in Mbire can possibly learn like those in other provinces of the country, Secondary schools in this district have been recording very low pass rates from 2006 to 2012 in science subjects namely Mathematics, Integrated Science and physical science. The results in these subjects have been comparatively low to those of the period 19982005 before the imposition of economic sanctions on Zimbabwe.

\subsection{Research Hypothesis}

In view of the issues raised above, the following null hypothesis (Ho) was generated to guide the study:

1. Children in Mbire can possibly learn the same way as other children of their age.

2. The political ecosystem in Zimbabwe has contributed more to the poor performance in the teaching and learning of science subjects in Mbire District.

3. Economic hardships caused by the Western imposed sanctions have had a negative impact on the teaching and learning of science subjects in Mbire.

\section{Methodology}

This study utilized a Descriptive survey methodology that sought to assess the effects of sanctions on science teaching and learning in Mbire District in Mashonaland Central Province. Descriptive survey design entails a study of limited number of cases with a view of drawing up conclusions that covers the generality of the whole group under review Borg and Garl (1998). Paper and pencil survey, interviews, observations and document study were the different methods employed as data gathering instruments. This was done to ensure trustworthiness and validity of the findings.

\subsection{Significance of the Study}

The results of this study, it is hoped will expose to a larger extent the reasons why pupils in Mbire district have been performing poorly in science subjects in public examinations from 2006 to 2012. The contributions of political and economic situation towards educational performance will be evaluated .Those results are very important to politicians, International organizations, teachers, education administrators and parents for they all have a role to play in policy formulation and in the learning of school children.

\subsection{Population Sample}

The study shall be limited to a small sample of five secondary schools in Mashonaland Central province focusing on schools in Mbire district. A purposively random sampling of 1045 Ordinary level pupils from the five selected secondary schools, their respective school heads and the District staffing officer are going to be used as a representative sample of secondary pupils and staff in Mbire district. The essence of sampling, Gay (1980) points out, is that it must accurately reflect the $10 \%$ of the population under study. The schools selected for study have been chosen on the strength of their enrolment size, as well as that these offer science subjects at O'Level. Another reason why these schools have been selected is that they fit well into the researcher's period of study since they were already established by 1980 . There is only one boarding government school in this district which is Mushumbi Government High and it has been included in this study. Other secondary schools include Mahuwe. Angwa, Musengezi which are all rural government schools and Makuvatsine that is run by Roman Catholic Church.

\subsection{Data Analysis Technique}

The data collected were assembled and summaries were made using the interpretational analysis technique. Interpretational analysis is the process of examining data closely in order to find constructs themes and explain phenomenon (which are all rural government 562).

\section{Discussion of Findings}

The findings of this study appear in three categories in which answers to research questions were provided and assessed using these three indicators.

\subsection{Data Analysis According to Sub-Themes}

Science Teacher -Pupil Ratio in Mbire from 2006-2012.

This research establishes that high failure rate in science subjects in Mbire does not mean that pupils are dull. The harsh economic conditions that hit the country from 2001 to 2012 as a result of sanctions drove many skilled workers and professionals outside the country to either neighbouring countries or abroad. By 2008 close to 45000 teachers were said to have left the country to neighbouring South Africa ,Swaziland,Botswana and Namibia where qualified teachers were in great demand especially science teachers (ZIMTA 2009). This uncontrolled brain drain paralysed schools in rural areas most. Brain drain is traditionally the movement of highly skilled workers from their home countries to countries that offer them greater 
opportunities in their area of specialization as well as living conditions and lifestyle (Mawere 2012). Massive brain drain which was aggravated by the poor remuneration of civil servants dealt a final blow to science teaching and learning in Mbire.

The diagram below Table1.0 illustrates the Science teacher Pupil Ratio in Mbire before and after sanctions.

Table 1.0. Science and maths teacher-pupil Ratio 1998-2000.

\begin{tabular}{llll}
\hline Name of School & $\begin{array}{l}\text { Statistics for 1998-2000 Student } \\
\text { Enrolment }\end{array}$ & $\begin{array}{l}\text { Science teachers per school } \\
\text { (qualified) }\end{array}$ & $\begin{array}{l}\text { Maths teachers per school } \\
\text { (qualified) }\end{array}$ \\
\hline Mushumbi High School & 702 & 4 & 2 \\
Musengezi Secondary & 349 & 3 & 2 \\
Mahuhwe High School & 1048 & 5 & 3 \\
Makuvatsine Secondary School & 1027 & 4 & 2 \\
Angwa Secondary School & 1011 & 3 & 1 \\
\hline
\end{tabular}

Source: District Education Office (2011)

The data derived from the statistics above indicate that before the imposition of sanctions, schools in Mbire had the services of qualified Science and Mathematics teachers. The overall teacher pupil ratio for science subjects in all schools is $+\backslash-1: 40$ (one science teacher per approximately 40 per form for secondary school pupils (Masuko 2003). One teacher can teach not more than three classes per week.

The District staffing officer for Mbire commented on the shortage of science teachers thus "...although the teacher pupil ratio was still high in the 1990s, the shortage of teachers in our district at this time could not be explained in terms of the brain drain but it was a national shortage."

This research prefers to explain the shortage in terms of a general shortage which was experienced countrywide but not in any way attached to economic crisis but to an inherited colonial education system which made science training a preserve of the whites by making entry requirements for science training more stringent for blacks.

Table 1.1. Science-teacher pupil ratio from 2006-2010.

\begin{tabular}{llll}
\hline \multirow{2}{*}{ Name of school } & Student enrolment & Science teachers per school (qualified) & Maths teachers per school (qualified) \\
\cline { 2 - 4 } & $\mathbf{2 0 0 6 - 2 0 1 0}$ & 1 & 0 \\
\hline Mushumbi High school & 618 & 0 & 0 \\
Musengezi secondary & 298 & 0 & 1 \\
Mahuhwe High school & 766 & 1 & 0 \\
Makuvatsine Secondary school & 635 & 0 & 0 \\
Angwa Secondary & 731 & 0 & \\
\hline
\end{tabular}

Source: District Education Office (2011)

Data derived from the above statistics show that there were only two (11\%) science teachers in the district compared to the 1998's total of 19 teachers. Teacher pupil ratio in Table1.1 is incalculable. There is no ratio to talk about.

Documentary study from the District Education Office in Mbire revealed that between 2006 and 2010 there was only one qualified Mathematics teacher. The District staffing officer for Guruve North reiterated that qualified science teachers joined the band wagon to South Africa where they were on high demand. Others transferred to urban schools to fill up posts left by teachers who went to South Africa or abroad. The district was in all these years employing qualified primary school teachers to teach in secondary schools though again with catastrophic implications on grade seven results in the district. The employment of primary trained teachers to teach at secondary school has had some adverse impact on content delivery to both primary and secondary levels. These findings confirm the allegations by Mbanje and Mahuku 2012) that sanctions which cause high economic damage on a country are likely to result in severe suffering among the general population than those targeted by the sanctions. For instance, between
2001 and 2008 salaries for teachers were an average of the equivalent US 276, 00 which was highly inadequate for the sustenance of their families. (ZimbabweTeachers' Association 2008 Report). Mbire District in particular and Zimbabwe in general are such case studies where the imposition of sanctions has paralysed the life of the ordinary people.

\subsubsection{Availability of Science Laboratory and Science Equipment}

All the school Heads interviewed indicated that their schools were crippled by critical shortages of science teaching and learning materials since the imposition of sanctions. This research noted shortages in major science textbooks, geometrical instruments, mathematical tables and laboratory apparatus like microscopes, bio viewers, venire callipers, test tubes and micrometer school gauge. Without these important laboratory instruments, the teaching and learning of science becomes a daunting task. This shortage means that children had limited individual private practice, a factor which this research used to explain high failure rate in Mbire. The research also noted that of all the five schools selected for study, none had a standing science laboratory. 
At Mushumbi High School, the headmaster Mr. Kazembe lamented that "...the school had plans to introduce Sciences at Advanced level but these were thwarted by the failure to complete the construction of the science laboratory which was started before the imposition of sanctions by donors"

The District staffing Officer Mr Mubatapasango further confirmed that "the whole district doesn't have a school offering sciences at Advanced level because of poor pass rate in sciences at Olevel that is compounded by shortages of teaching and learning materials.

This study discovered that the construction of a science lab which had started in 1998 at Mushumbi government school was still incomplete because since then the school had not received any financial assistance from the state. The school uses up to now an ordinary classroom that has been converted for the purpose though with little pedagogical effectiveness. The worst impact that the research noted in this respect was the dropping of Physical science at all schools in the district (Including schools out of this study). There are 16(sixteen) registered secondary schools in this district but none of them offers physical science at ordinary level.

We are not producing artisans, neither Doctors nor Engineers in this district; our school leavers end up in the streets because they cannot compete on the job market without Maths and sciences says the District Education Officer.

At Mahuhwe high school, physical science was last sat for at O'level in 2005 when the science teacher was still there. At Makuvatsine the last physical science exam was sat for in 2006, while Mushumbi continued to offer Physical science up to the period of study but has been recording $0 \%$ pass rate. Schools in Mbire district are now offering integrated science at O'level which is less demanding on both teaching resources and instruction. However, the weakness of this subject is that a student who passes it cannot proceed to Advanced level to study sciences since this is only regarded as an introductory paper to the study of science.

\subsubsection{Science Pass Rate against Schools Overall Pass Rates}

A cluster of variables linked to sanctions have been implicated in this research as responsible for the dismal performance of students. These include, governance related variables, teacher-student ratio and text-book (resource material) related variables. However these alone can give an account for and not an accurate account of the science subjects' failure rate.

The statistics below indicates how science subjects fared against overall schools pass rates. The schools pass rates represented herein are for those who passed five subjects and above with grade $\mathrm{C}$ or better against the mathematics and science pass rate. The total number of candidates who sat for Ordinary level examinations in five subjects and above at each school each year is indicated in brackets.

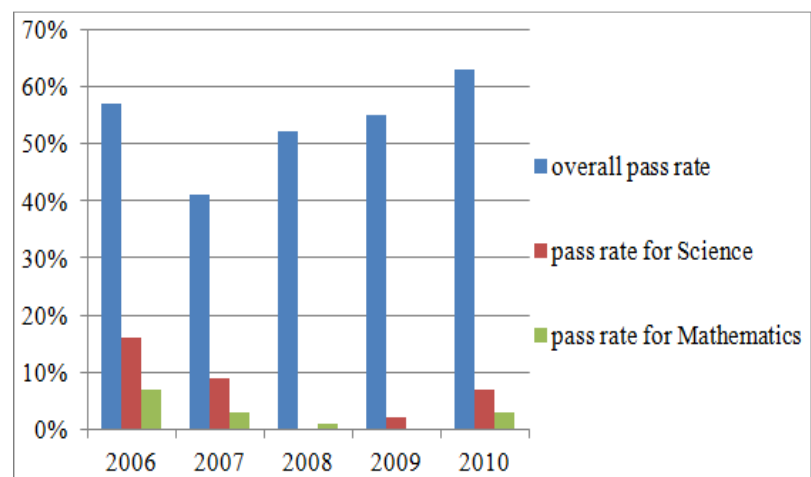

Figure 1. Mushumbi Secondary School

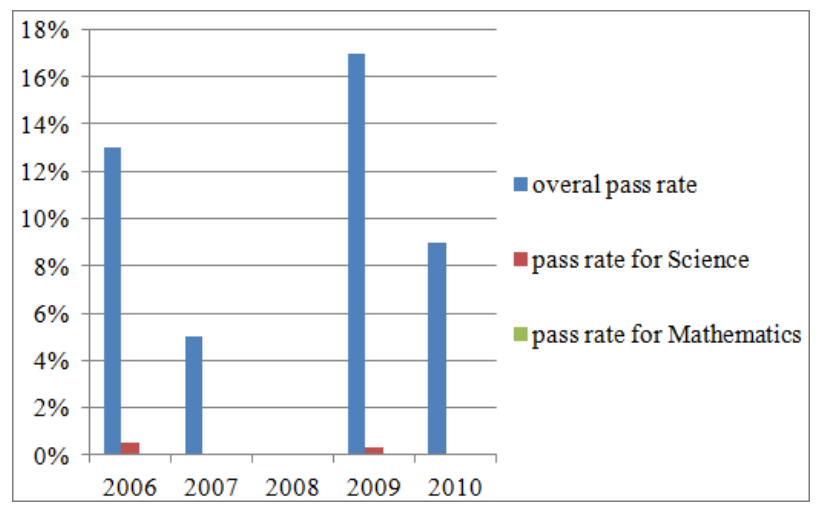

Figure 2. Musengezi Secondary School

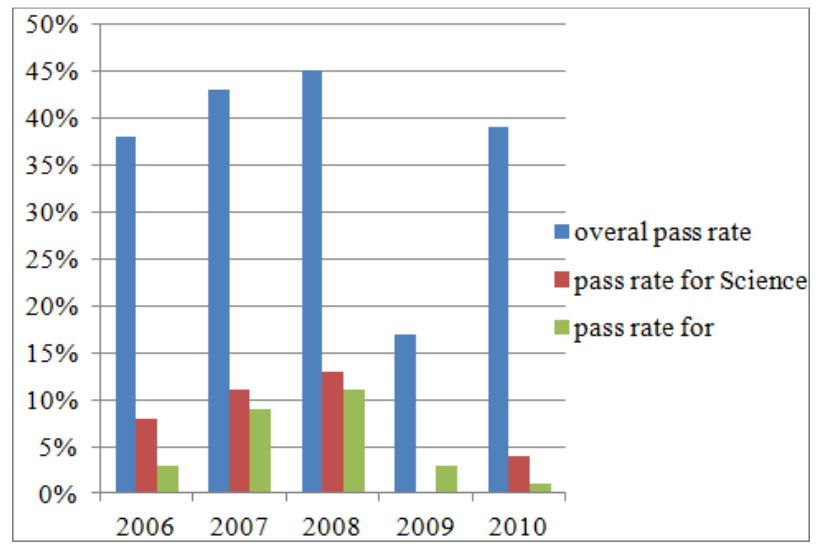

Figure 3. Mahuwe Secondary School

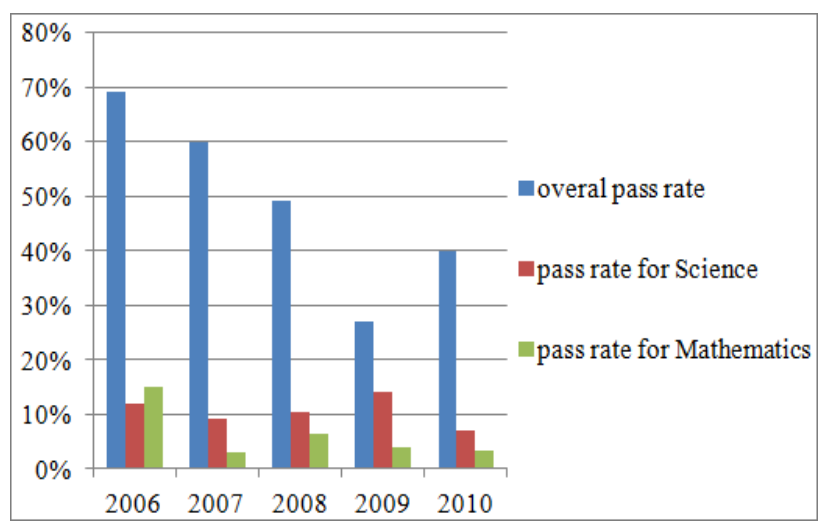

Figure 4. Makuwatsine Secondary School 


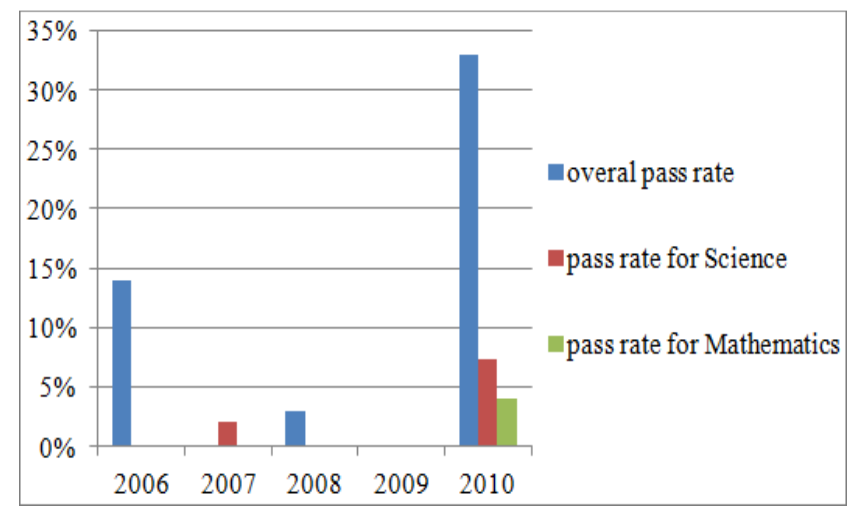

Figure 5. Angwa Secondary School

Source: District education office (2011)

Data derived from documents study indicate that science and maths have been poorly performed in Mbire between 2006 and 2010.This is the period when the country's economy was hard hit by sanctions. Pupils in Mbire performed averagely in arts and commercial subjects. This paper noted that surveyed schools in Mbire were affected differently by economic sanctions. The most affected are government and council schools that relied on government grants for purchase of science equipment and text books. At Makuvatsine, the church hired the services of nuns and Jesuits to teach sciences and maths. This is why their pass rate has been comparatively higher than in other schools.

The social background (environment) of children in Mbire may be miles away from expected learning environment. Weinberg (1989) reiterated that genes ...react to the possible experiences that the environment can provide. Environment in this case ranges from the type of food the child eat, the kind of motivation a child receives from teachers and parents, learning resources as well as the quality of instruction a child receives.

\section{Conclusion and Recommendations}

Harsh economic climate mostly created by the economic sanctions has made it difficult or impossible for many parents to afford school fees and other related costs. The district lacks facilities like electricity, libraries, computers, textbooks and good transport network. Against such a hindering social environment educationists in Mbire have a challenge to bring closer to pupils' cognition the favourable environment for them to learn?

There must be dialogue between Zimbabwe on one hand, Britain, USA, and Australia on the other particularly on the issue of sanctions since these have devastated the life of the ordinary people.

These opposing parties must negotiate to mend their relations for the good of ordinary Zimbabweans.

Economic sanctions in Zimbabwe should be lifted because the so called "targeted" people are not affected by them.

\section{References}

[1] Burton, J.B.(2002) "Economic Sanctions: The Institutional Factor", Canadian Journal of Development Studies, 23(1): 27-46. (On Line) at: http://hetcorporation.ca/wpcontent/uploads/2009/05/economic sanctions.pdf

[2] Chetsanga, C. J. (2002). An analysis of the causes and effects of brain drain in Zimbabwe. Harare: Scientific and Industrial Development Centre.

[3] Chigora,P.,and Dewa, D.(2009), "Surviving in a hostile Environment: An Analysis of Zimbabwe's Foreign Relations in 21stCentury International Relations" African Journal of political science and International Relations, 3(3): 92-98

[4] Chingono, H.(2010), "Zimbabwe Sanctions: An analysis of the 'Lingo'guiding the perceptions of the sanctions and the sanctioneers". African Journal of political sciences and International Relations, 4(2): 66-74 (On Line) at http://www.academicjournals.org/ajsiron23/07/10.

[5] Chombo,I.(1998), 'The human factor and education content in Zimbabwe' in Vimbai Chivaura and Mararike C.C (eds).The Human Factor Approach to Development in Africa, Harare, Zimbabwe, University of Zimbabwe Publications.

[6] Darling-Hammond,(1999) Teacher Quality and Student Achievement: A Review of State Policy Evidence, Center for the Study of Teaching and Policy, University of Washington, Seattle, WA, 1999, Internet: http://depts.washington.edu/ctpmail/PDFs

[7] Finnegan, W. (2002), "Economic Sanctions" The New Yorker. (April 18), pp43-53

[8] Hondora,T.(2008). Economic Sanctions undermine Zimbabwe's economy.Retrievedfrom http://www.newzimbabwe.com/pages/sanctions32.13170.ht $\mathrm{ml}$

[9] Ingersoll (2000), Turnover Among Mathematics and Science Teachers in the U.S., National Commission on Mathematics and Science Teaching for the 21st Century, Internet: http://www.ed.gov/inits/Math/glenn/Ingersollp.doc

[10] Ingersoll (2001). Teacher Turnover, Teacher Shortages, and the Organization of Schools, Internet: $\mathrm{http} / / /$ depts.washington.edu/ctpmail/PDFs/Turnover-Ing-012001.pdf

[11] Mushonga, M.(2005). Brain drain dilemma in Zimbabwe: factors, extent and alternatives in the new millennium", paper presented at the SAARDHE Conference, Durban, 2629 June.

[12] Mutume, G. (2003).Reversing Africa's brain drain: new initiatives tap skills of African experts", Zambia Daily Mail, 25 July.

[13] Odunsi, B.A.(1996). An analysis of brain drain and its impact on manpower development in Nigeria", Journal of Third World Studies, 13(Spring): 193-214.

[14] Torbat,A.E.(2005). "Impact of the US Trade and Financial Sanctions on Iran" The world economy journal. 
[15] H. Wenglinsky, How Teaching Matters: Bringing the Classroom Back into Discussions of Teacher Quality, Educational Testing Service, Princeton, NJ, 2000, Internet: http://www.ets.org/research/pic/teamat.pdf
[16] Zvobgo, C. J (1999) Post-colonial state and educational Reform. (Zimbabwe, Zambia and Botswana), Harare: College Press. 